\title{
Impact of bullying \& cyberbullying on body image and disordered eating in young adult females
}

\author{
Ross King*, Rebecca Moorfoot, Mary Kotronakis \\ From 2015 ANZAED Conference: Riding the Waves to Recovery \\ Surfers Paradise, Australia. 21-22 August 2015
}

\begin{abstract}
Weight related teasing, a verbal form of bullying, is an established predictor of body dissatisfaction and disordered eating. However, as many as $11 \%$ of university students report experiencing other forms of bullying, such as physical, social, and cyberbullying which has been linked to depression, anxiety and substance abuse. The current study aims to establish the impact of other forms of bullying on body dissatisfaction and disordered eating. Female participants (123) aged $18-25$ years completed an anonymous online survey comprising measures of the frequency and effect of teasing, other forms of bullying, negative affect, social comparison, internalisation, body dissatisfaction, and disordered eating. Significant correlations existed between weight-related teasing, physical bullying frequency and social bullying effect but not cyberbullying and body dissatisfaction, drive for thinness and bulimic symptoms. Internalisation, appearance-based social comparison, and levels of negative affect were examined as mediators of the relationships between social and physical bullying with bulimia, drive for thinness and body dissatisfaction with support for partial or full mediation identified for many relationships. These findings further our understanding of the broader consequences of bullying and the factors that mediate this relationship, and can assist in the development of targeted preventative strategies to minimise these impacts.
\end{abstract}

Published: 23 November 2015

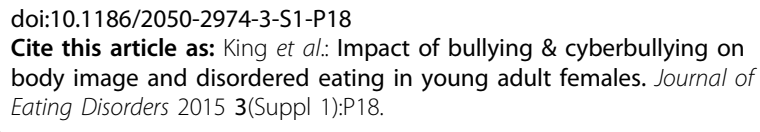

* Correspondence: rking@deakin.edu.au

School of Psychology, Deakin University, Victoria, Australia
Submit your next manuscript to BioMed Central and take full advantage of:

- Convenient online submission

- Thorough peer review

- No space constraints or color figure charges

- Immediate publication on acceptance

- Inclusion in PubMed, CAS, Scopus and Google Scholar

- Research which is freely available for redistribution
() Biomed Central
C Biomed Central

(C) 2015 King et al. This is an Open Access article distributed under the terms of the Creative Commons Attribution License (http:// creativecommons.org/licenses/by/4.0), which permits unrestricted use, distribution, and reproduction in any medium, provided the original work is properly cited. The Creative Commons Public Domain Dedication waiver (http://creativecommons.org/publicdomain/ zero/1.0/) applies to the data made available in this article, unless otherwise stated. 